\title{
Evaluasi Kebijakan Penerimaan Peserta Didik Baru (PPDB) dengan Sistem Zonasi pada SMA Negeri di Kota Padang
}

\author{
Messy Ani Safitri, Rahmadani Yusran \\ Jurusan Ilmu Administrasi Negara \\ FIS Universitas Negeri Padang \\ E-mail: yusranrdy@fis.unp.ac.id
}

\section{ABSTRAK}

Penelitian ini bertujuan untuk melihat dampak kebijakan PPDB dengan sistem zonasi pada SMAN di Kota Padang. Tujuan kebijakan PPDB dengan sistem zonasi berdasarkan Permendikbud Nomor 44 Tahun 2019 untuk peningkatan akses layanan pendidikan.Teknik pengumpulan data dilakukan dengan cara wawancara, observasi, dan studi dokumentasi serta dilakukan reduksi data agar bisa ditarik kesimpulan yang akurat dari data yang telah didapat. Hasil penelitian menunjukkan pelaksanaan kebijakan PPDB zonasi di Kota Padang mengalami berbagai peramasalahan, sehingga mondorong munculnya pro dan kontra. Pemerintah sebagai pihak implementor menyatakan PPDB dengan sistem zonasi pada SMAN di Kota Padang terlaksana dengan baik serta tujuannya sudah tercapai dengan mudahnya peserta didik yang dekat dengan sekolah untuk masuk ke sekolah tersebut. Namun masyarakat sebagai objek yang terkena dampak kebijakan tersebut menyatakan banyak permasalahan yang terjadi dalam pelaksanaan sistem zonasi diantaranya, belum terpenuhinya transparansi, akuntabilitas dan keadilan dalam akses layanan pendidikan. Penelitian ini, menyimpulkan kebijakan PPDB zonasi di Kota Padang adalah strategi terutama diera digital ini. Hal ini, karena kebijakan ini dapat menjamin kemudahan dalam akses pelayanan pendidikan, transparansi, akuntabilitas dan keadilan bagi masyarakat. Namun demikian, kebijakan PPDB zonasi di Kota Padang belum terlaksana sebagaimana mestinya, sehingga berdampak pada semakin sulitnya mewujudkan capaian tujuan kebijakan.

Kata Kunci: evaluasi kebijakan, PPDB Zonasi, SMAN Padang ABSTRACT

This study aims to see the impact of PPDB zoning at SMAN in Padang City. The goal of PPDB zoning based on Permendikbud Number 44 of 2019 is to increase access to education services. Data collection techniques are carried out by interviewing, observing, and studying documentation and data reduction so that accurate conclusions can be drawn from the data that has been obtained. The results showed that the implementation of the PPDB zoning policy in the city of Padang experienced various problems, thus encouraging the emergence of pros and cons. The government as the implementor stated that PPDB with the zoning system at SMAN in Padang City was carried out well and the goal was easily achieved by students close to the school to enter the school. However, the community as the 
object affected by the policy stated that there were many problems that occurred in the implementation of the zoning system, including the lack of transparency, accountability and justice in access to education services. This research concludes that the PPDB zoning policy in the city of Padang is a strategy, especially in this digital era. This is because this policy can guarantee easy access to education services, transparency, accountability and justice for the community. However, the PPDB zoning policy in the city of Padang has not been implemented as it should be, so that it has an impact on the difficulty of realizing the achievement of policy objectives.

Keywords: Policy Evaluation, PPDB Zoning, SMAN Padang

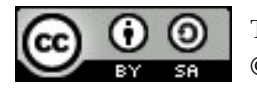
(c) This work is licens Received: Sept 302020

\section{PENDAHULUAN}

Sistem zonasi merupakan sistem yang menuntut peserta didik baru memilih sekolah dengan radius terdekat sesuai domisli peserta didik. Kebijakan Penerimaan Peserta Didik Baru (PPDB) dengan sistem zonasi merupakan alternatif kebijakan dalam mengatasi berbagai permasalahan dalam penerimaan siswa di sekolah. Sejak tahun 2016, pemerintah telah melaksanakan kebijakan ini di berbagai daerah di Indonesia.

Di Indonesia kebijakan PPDB dengan pendekatan sistem zonasi juga dimanfaatkan membenahi berbagai standar nasional pendidikan seperti kurikulum, sebaran guru, sebaran peserta didik serta kualitas sarana dan prasarana, berbasis zonasi (Effendy:2019). Namun, implementasi kebijakan zonasi baru dilaksanakan secara bertahap sejak tahun 2016. Pada tahun ini, sistem zonasi diselenggarakan pada Ujian Nasional (UN). Kemudian baru pada tahun 2017 sistem zonasi pertama kali diterapkan dalam PPDB berdasarkan Permendikbud Nomor 17 Tahun 2017. Selanjutnya, Permendikbud tersebut direvisi dan diganti dengan Permendikbud Nomor 14 Tahun 2018 tentang Penerimaan Peserta Didik Baru pada Taman Kanak-Kanak, Sekolah Dasar, Sekolah Menengah Pertama, Sekolah Menengah Atas dan Sekolah Kejuruan, atau bentuk lain yang Sederajat. Pada akhir tahun 2018, Permendikbud tersebut juga diganti dengan Permendikbud No.51 Tahun 2018 tentang Penerimaan Peserta Didik Baru.

Namun demikian, implementasi Permendikbud No 51 Tahun 2018 juga memiliki berbagai kelemahan. Diantaranya, ada sejumlah permasalahan dalam penerapan sistem zonasi ini, yang paling menonjol adalah sedikitnya kuota jalur berprestasi luar zona yang hanya 5 persen (Ganjar Pranowo:2019). Fenomena inilah, yang kemudian mendorong diterbitkannya Instruksi Persiden yang bertujuan untuk mengevaluasi sistem zonasi PPDB ini. Berdasarkan fenomena di atas, Menteri Pendidikan dan Kebudayaan pada Juni tahun 2019 kembali merevisi Permendikbud 
Nomor 51 Tahun 2018 dan mengeluarkan Surat Edaran Mendikbud Nomor 3 Tahun 2019 Tentang Perubahan Atas Peraturan Menteri Pendidikan dan Kebudayaan Nomor 51 Tahun 2018 Tentang Penerimaan Peserta Didik Baru Pada Taman Kanak-Kanak, Sekolah Dasar, Sekolah Menengah Atas Dan Sekolah Menengah Kejuruan.

Surat Edaran ini antara lain mengatur tentang ketentuan persentase dalam PPDB: 1) Jalur zonasi yang awalnya paling sedikit 90\% menjadi $80 \%$ dari daya tampung sekolah; 2) Jalur prestasi yang paling banyak $5 \%$ menjadi $15 \%$ dari daya tampung sekolah; dan 3) Jalur perpindahan tugas orang tua/wali tetap paling banyak $5 \%$ dari daya tampung sekolah.

Kemudian SE Mendikbud No 3 Tahun 2019 tersebut diundangkan dalam Berita Negara Republik Indonesia Tahun 2019 Nomor 669 di Jakarta tanggal 20 Juni 2019 menjadi Permendikbud Nomor 20 Tahun 2019 tentang Penerimaan Peserta Didik Baru. Namun diakhir tahun 2019 peraturan PPDB dengan sistem zonasi juga diganti dengan Permendikbud Nomor 44 Tahun 2019. Berdasarkan Permendikbud Nomor 44 Tahun 2019 PPDB dengan zonasi dilaksanakan di Indonesia saat ini.

Selanjutnya, sesuai dengan ketentuan Permendikbud No 44 Tahun 2019 ditetapkan bahwa tujuan utama dari kebijakan sistem zonasi PPDB ini adalah peningkatan akses layanan pendidikan serta pedoman kepala daerah membuat kebijakan teknis dan kepala sekolah dalam melaksanakan PPDB. Lebih jauh ditegaskan oleh Mendikbud bahwa sistem zonasi PPDB ini juga bertujuan memberikan akses dan keadilan pendidikan bagi kalangan masyarakat. Selain itu, juga bertujuan untuk mengubah stereotip 'sekolah unggulan'. Hal ini, karena selama ini sekolah 'unggulan' sering identik dengan siswa pintar dan memiliki kemampuan ekonomi menengah keatas serta juga bertujuan untuk meminimalisir jarak tempuh siswa dari rumah ke sekolah (Muhadjir Effendy:2019).

Di Sumatera Barat, implementasi kebijakan PPDB dengan sistem zonasi ditetapkan dalam Pasal 13 ayat 1 Pergub Sumatera Barat No 22 Tahun 2018 tentang Penerimaan Peserta Didik Baru pada Sekolah Menengah Atas, Sekolah Menengah Kejuruan, dan Sekolah Luar Biasa Negeri bahwa PPDB dilaksanakan dengan sistem online zona Kabupaten/Kota. Penerapan zonasi Kabupaten/Kota di Kota Padang dikarenakan sebaran sekolah tidak merata. Penerapan zonasi berdasarkan zonasi tempat tinggal berdampak terhadap pemerataan sebaran siswa, ada sekolah yang tidak mencukupi kuota dan sebaliknya sekolah yang berada di lingkungan padat penduduk bisa melebihi kuota (Adib Alfikri:2019).

Pada Juni tahun 2020, Pergub No 22 Tahun 2018 diganti dengan Pergub Sumatera Barat Nomor 40 Tahun 2020 sesuai dengan Permendikbud Nomor 44 Tahun 2019. Dari pergantian Pergub ini, terlihat pada tahun 2018 kebijakan PPDB di Sumatera Barat dilaksanakan dengan sistem zonasi kabupaten dan kota. Sedangkan pada tahun 2020 PPDB dilaksanakan dengan sistem zonasi secara murni sesuai dengan jarak rumah terdekat ke sekolah. Sesuai 
Journal of Civic Education (ISSN: 2622-237X)

Volume 4 No. 12021

dengan Pergub Sumbar Nomor 40 Tahun 2020, kebijakan PPDB dengan sistem zonasi dilaksanakan berdasarkan Pertama, dilaksanakan berdasarkan asas transparansi, non diskriminatif, objektif, akuntabel dan berkeadilan; Kedua, Pelaksaan PPDB untuk jalur SMA dilaksanakan melalui jalur: a) Zonasi dengan persentase $50 \%$ dari daya tampung sekolah, yang dibuktikan dengan Kartu Keluarga 1 tahun terakhir. b) Afirmasi dengan persentase 15\% dari daya tampung sekolah, yang dibuktikan dengan kartu kurang mampu dari pemerintah, misalnya pkh. c) Perpindahan orang tua dengan persentase 5\% dari daya tampung sekolah dan d) Prestasi dengan persentase $30 \%$ dari daya tampung sekolah; Ketiga, pendaftarannya dilakukan secara daring melalui website http://ppdbsumbar2020.id.

Dalam pelaksanaanya di Kota Padang, PPDB dengan sistem zonasi dilakukan dalam tiga tahap. Tahap pertama dan kedua sesuai dengan Pergub Sumbar No. 40 Tahun 2020 yang dilakukan secara daring. Sedangkan tahap ketiga adalah tahap optimalisasi atau pemenuhan bagi sekolah yang masih ada daya tampungnya yang dilakukan secara offline, dan penerimaannya dalam tahap ketiga ini berdasarkan nilai siswa, bukan berdasarkan zonasi lagi.

Namun implementasi

kebijakan PPDB dengan sistem zonasi mengalami berbagai permasalahan di Kota Padang. Hal ini, disebabkan karena adanya anggapan kebijakan PPDB belum dipersiapkan dan dikaji secara komprehensif (Ady Akbar:2019). Hal ini dapat dilihat dari: 1) Persebaran sekolah yang tidak merata didaerah kabupaten dan kecamatan sehingga terjadi ketimpangan jumlah siswa antara sekolah satu dengan lainnya; 2) Pendistribusian guru tidak merata di daerah, di sekolah tertentu ada yang kelebihan guru dan ada yang kekurangan guru; 3) Sarana dan prasarana juga tidak merata bahkan ada beberapa sekolah didaerah terpencil masih banyak yang tidak layak (Ady Akbar:2019). Kondisi ini, juga dipengaruhi oleh keadaan persebaran sekolah yang tidak merata dengan persebaran penduduk di Kota Padang mengakibatkan blankzone yang artinya adanya daerah yang tidak masuk dalam radius zonasi, sehingga siswa yang berada di daerah tersebut sulit untuk besekolah.

Fenomena di atas menimbulkan dampak yang signifikan terhadap capaian tujuan kebijakan PPDB. Pertama, dampak terhadap akses pelayanan Pendidikan. Akses pelayanan Pendidikan bertujuan untuk memberikan kemudahan kepada masyarakat untuk masuk ke sekolah tertentu. Memang pada satu sisi memberikan dampak baik bagi siswa yang dekat dengan sekolah, namun pada sisi lain merugikan peserta didik yang jauh dari sekolah. Inilah kelemahan zonasi yang diterapkan di Kota Padang. Kedua, dalam pelaksanaan PPDB dengan sistem zonasi di Kota Padang dinilai kurang transparan dan akuntabel, hal ini dibuktikan dengan temuan dilapangan terkait beberapa masalah, diantaranya, server yang down serta peta google yang kurang akurat dalam penetapan domisili peserta didik. Tentunya hal ini merugikan masyarakat.

Ketiga, dampak pelaksanaan kebijakan PPDB dengan sistem zonasi 
dalam memenuhi keadilan. Pendekatan zonasi yang dimulai dari penerimaan siswa baru dimaksudkan untuk memberikan akses yang lebih setara dan berkeadilan kepada peserta didik. Tanpa melihat latar belakang kemampuan ataupun perbedaan status sosial ekonomi. Sebagian masyarakat Kota Padang beranggapan kuota yang disediakan untuk masyarakat miskin masuk disekolah tertentu sangat kecil, yaitu sekitar 15 persen.

\section{METODE PENELITIAN}

Penelitian ini menggunakan pendekatan kualitatif dengan metode deskriptif. Lokasi penelitian ini dilakukan di Dinas Pendidikan Sumatera Barat, SMAN 12 dan 16 kota Padang serta masyarakat yang tinggal di dekat SMAN 12 dan 16 kota Padang. Bogdan dan Taylor (dalam Winarno, 2002:22), mengungkapkan penelitian kualitatif sebagai prosedur penelitian yang menghasilkan data deskriptif berupa kata-kata tertulis, lisan dari orang-orang dan perilaku yang dapat diamati. Oleh karena itu, pemilihan Informan penelitian adalah orang-orang yang memahami permasalahan yang diteliti. Informan penelitian ini adalah Koordinator Kurikulum dan Kesiswaan B.PSMA Disdik Sumbar, Wakil Kesiswaan di SMAN 12 Padang, Sekretaris PPDB di SMAN 16 Padang, serta masyarakat sekitar dan siswa yang diterimadi sekolah tersebut. Teknik pengumpulan data melalui wawancara, observasi, dan studi dokumentasi. Uji keabsahan data menggunakan teknik triangulasi dan referensi yang relevan. Selanjutnya, data yang diperoleh dianalisis melalui tahap reduksi data, penyajian data dan penarikan kesimpulan.
HASIL DAN PEMBAHASAN

Dampak dari Implementasi Kebijakan Penerimaan Peserta Didik Baru dengan Sistem Zonasi pada SMAN 12 dan 16 Kota Padang

Evaluasi pada dasarnya sering digunakan melihat sejauh mana program-program kebijakan menimbulkan dampak yang diinginkan. Oleh karena itu, evaluasi kebijakan diklasifikasikan dalam dua tugas berbeda. Pertama, menentukan konsekuensi yang ditimbulkan kebijakan dengan menggambarkan dampaknya. Kedua, evaluasi kebijakan bertujuan memberikan penilaian keberhasilan atau kegagalan kebijakan berdasarkan standar atau kriteria yang telah ditetapkan. Dengan demikian, melakukan evaluasi kebijakan PPDB dengan sistem zonasi pada dasarnya berusaha menggambarkan apakah ada dampak yang signifikan bagi kemajuan dalam pelaksanaan pendidikan di Kota Padang (R. Yusran, 2007).

Hal ini dikarenakan alasan mendasar pemerintah menerapkan kebijakan PPDB dengan sistem zonasi berkaitan erat dengan upaya pemerataan kualitas pendidikan kedepannya. Pertama, menghapuskan anggapan sekolah favorit, karena pada dasarnya sekolah favorit itu tidak ada, karena tujuan siswa adalah belajar dan menuntut ilmu bukan mencari sekolah favorit. Kedua, untuk pemerataan bantuan semua sekolah, karena selama ini yang mendapatkan bantuan paling banyak adalah sekolah yang dianggap favorit. Ketiga, untuk meningkatkan kompetensi guru, karena selama ini siswa-siswa yang pintar hanya ada di sekolah yang dianggap favorit, dengan sistem 
zonasi ini bisa menciptakan siswa yang heterogen, agar gurunya lebih bersemangat dalam menjalankan tugasnya, dan yang terakhir untuk menghemat biaya transportasi, karena sekolah lebih dekat kerumah, hanya saja dalam pelaksaanya yang tidak sesuai aturan serta juga memiliki kelemahan. Sehingga pelaksaaanya tidak berjalan dengan baik dan tujuanya tidak bisa tercapai.

Winarno

(2002:228-229) mengungkapkan evaluasi kebijakan adalah langkah terakhir dalam tahapan proses kebijakan. Evaluasi merupakan kegiatan fungsional dalam proses kebijakan, dimana aktivitasnya tidak hanya dilakukan pada tahap akhir saja tetapi dapat dilakukan pada semua proses kebijakan publik perumusan masalah, implementasi, serta dampak kebijakan, evaluasi adalah kegiatan penilaian kebijakan yang bertujuan melihat sebab-sebab kegagalan suatu kebijakan atau kebijakan publik telah mencapai dampak yang diharapkan.

Evaluasi pelaksanaan kebijakan PPDB dengan sistem zonasi di Kota Padang dalam penelitian ini mengacu kepada kriteria evaluasi Dunn dalam Mulyadi (2016: 87). Dalam teori tersebut, Dunn menjelaskan bahwa evaluasi kebijakan berkiatan dengan kinerja kebijakan terutama pada implementasi kebijakan publik. Kriteria indikator evaluasi yang peneliti gunakan menilai pelaksanaan PPDB dengan sistem zonasi di kota Padang yaitu efektivitas, efisiensi, dan responsivitas.

Pertama, efektivitas pelaksanaan kebijakan PPDB dengan sistem zonasi mengacu kepada Dunn dalam Mulyadi (2016: 124). Efektivitas pada hakekatnya berkaitan dengan optimalisasi pencapaian hasil/tujuan kebijakan yang sudah ditetapkan. Dalam konteks kebijakan PPDB dengan sistem zonasi, optimalisasi pencapaian hasil/tujuan kebijakan sesuai dengan Permendikbud Nomor 44 Tahun 2019. Pada aspek tertentu PPDB dengan sistem zonasi di Kota Padang sudah mencapai tujuan berkaitan dengan hal kepala daerah dalam pembuatan kebijakan teknis PPDB dengan sistem zonasi yang dituangkan dalam Pergub Sumatera Barat No 40 Tahun 2020. Tapi pada aspek lain, tujuan utama kebijakan PPDB dengan sistem zonasi belum tercapai. Misalnya, dalam peningkatan akses layanan pendidikan atau kemudahan untuk masuk ke sekolah bagi sebagian besar masyarakat mengalami kesulitan. Sistem zonasi dianggap tidak memberikan akses yang luas dan mudah. Hal ini, dikarenakan persebaran sekolah yang tidak merata dibandingkan dengan persebaran penduduk di Kota Padang.

Pada satu sisi memang memberikan kemudahan bagi peserta didik untuk bersekolah didekat rumahnya. Namun pada sisi lain merugikan peserta didik yang berada pada wilayah blankzone yang artinya lokasi yang tak terjangkau oleh radius zonasi atau daya tampung sekolah tidak mencapai wilayah tersebut. Akibatnya, banyak peserta didik yang tinggal didaerah tersebut kesulitan untuk bersekolah, ditambah lagi beberapa dari peserta didik yang tinggal didareah blankzone tersebut juga tidak bisa masuk dengan jalur yang lain. Misalnya, jalur prestasi, tapi nilainya tidak mencukupi, atau melalui jalur afirmasi. Umumnya, mereka bukan dari keluarga kurang 
mampu atau dari keluarga yang kurang mampu tapi kuotanya yang sudah penuh. Sehingga mereka hanya bisa pasrah saja dengan keadaan yang ada. Inilah salah satu bentuk kelemahan sistem zonasi.

Kedua, efisiensi pelaksanaan kebijakan PPDB denga sistem zonasi. Menurut Dunn (1999: 608-609). Efisiensi berkaitan dengan usaha menghasilkan tingkat efektivitas tertentu. Lebih jauh Dunn (1999: 608609), mengungkapkan, salah satu fungsi penting evaluasi kebijakan adalah memberikan informasi valid, terpercaya dari kinerja suatu kebijakan, yakni seberapa jauh kebutuhan, nilai, kesempatan serta tujuan yang dicapai suatu tindakan publik. Dengan demikian, evaluasi dapat mengungkapkan seberapa jauh tujuan dan target kebijakan tertentu dicapai dan memecahkan masalah.

Mengacu kepada Dunn (1999: 608-609) berkaitan dengan efisiensi pelaksanaan kebijakan PPDB sistem zonasi di Kota Padang, maka optimalisasi capaian kinerja kebijakan dilihat dari upaya pemerintah Kota Padang mewujudkan tujuan kebijakan melalui akses pelayanan pendidikan, transparasi, akuntabilitas keadilan. Namun, berdasarkan temuan di lapangan, pelaksaan PPDB sistem zonasi di Kota Padang belum efisien dan mengalami banyak permasalahan. Contohnya; Pertama, pelaksanaan kebijakan PPDB dengan sistem zonasi tidak transparan. Sistem zonasi dilaksanakan berbasis google map (dilihat dari peta google) dalam penetapan titik koordinat domisili, seringkali tidak akurat. Bahkan, ada masyarakat yang jarak rumahnya berada pada lokasi yang sama, ketika pendaftaran jarak rumahnya berbeda pada peta google. Akibatknya, salah satunya diterima dan satunya lagi tidak diterima.

Terkait dengan peta google yang kurang akurat dalam penetapan titik koordinat domisili, pemerintah daerah hanya menyatakan bahwa itu sudah sesuai dengan sistem. Padahal harusnya juga ada pengontrolan langsung dari pihak pemerintah daerah, sistem itu juga bisa salah, karena juga dibuat oleh manusia, dengan adanya permasalahan seperti tentunya bisa merugikan masyarakat. Contoh lainnya adalah adanya indikasi jual beli kursi yang dilakukan oknum sekolah ditahap optimaliasi atau pemenuhan daya tampung sekolah yang pelaksaaanya dilakukan secara luring.

Ketiga, adanya indikasi yang mencerminkan tindakan yang tidak akuntabel dalam melaksanakan kebijakan PPDB. Indikasi ini, diperoleh dari informan penelitian yang ditemui. Ada sejumlah keterangan yang mengungkapkan bahwa adanya tindakan dan perilaku bertentangan dengan peraturan pembuatan alamat palsu didekat sekolah yang dianggap unggul oleh masyarakat Kota Padang, dengan tujuan agar anak mereka bisa masuk ke sekolah tersebut, namun ketika di konfirmasi, pihak dinas menyatakan itu bukan wewenang mereka. Padahal dalam pelaksanaanya menurut pemendikbud, Pemda wajib melakukan pembinaan dan pengawasan terhadap sekolah yang diselenggarakan Pemda dan masyarakat diwilayahnya. Tidak hanya itu, pemerintah daerah juga dinilai tidak maksimal dalam melakukan sosialisasi sehingga banyak masyarakat yang 
Journal of Civic Education (ISSN: 2622-237X)

Volume 4 No. 12021

kebingungan dalam melakukan pendaftaran secara daring.

Ditambah lagi server yang down ketika masyarakat melakukan pendaftaran. Namun pemerintah daerah beranggapan itu adalah hal yang wajar. Seharusnya sebelum pelaksanaanya sudah harus disiapkan semaksimal mungkin. Temuan ini juga sejalan dengan pendapat Dunn mengenai salah satu karakteristik evaluasi kebijakan yaitu Interdependensi fakta nilai. Maksudnya adalah untuk membuktikan suatu kebijakan telah mencapai tingkat kinerja yang tertinggi atau sebaliknya. Tidak hanya hasil kebijakan yang bermanfaat bagi individu, kelompok atau masyarakat perlu didukung juga oleh bukti bahwa hasil-hasil kebijakan secara actual sebagai konsekuensi dari tindakan memecahkan masalah tertentu.

Keempat, berkaitan dengan Responsivitas pelaksanaan kebijakan PPDB sistem zonasi di Kota Padang belum sesuai dengan kebutuhan masyarakat. Responsivitas ini menurut Dunn berkaitan dengan upaya menentukan seberapa jauh suatu kebijakan memuaskan kebutuhan, preferensi nilai masyarakat. Manakala pelaksanaan kebijakan memenuhi kebutuhan atau preferensi nilai masyarakat, maka dapat dikatakan capaian tujuan kebijakan sudah terwujud. Namun demikian, berdasarkan dampak pelaksanaan kebijakan PPDB dengan sistem zonasi di Kota Padang dalam aspek keadilan belum tercapai.

Pendekatan zonasi penerimaan siswa baru dimaksudkan memberikan akses yang berkeadilan kepada peserta didik. Tanpa adanya upaya untuk membedakan latar belakang, status dan kemampuan sosial ekonomi masyarakat. Sebagaian masyarakat beranggapan kuota yang disediakan untuk masyarakat miskin masuk disekolah tertentu sangat kecil, yaitu sekitar 15 persen. Jumlah ini sangat kecil, dibandingkan jumlah masyarakat miskin di Kota Padang sebesar 344,23 ribu orang menurut data BPS Kota Padang pada bulan Maret tahun 2020. Dampak dari kuota yang kecil ini, masyarakat miskin mendaftarkan anak-anak mereka pada sekolah-sekolah swasta dengan beban biaya lebih besar. Mestinya, dengan adanya sistem zonasi ini, anak-anak dari keluarga masyarakat miskin berpeluang untuk bersekolah pada sekolah yang diminati.

Berdasarkan uraian diatas, peneliti berpendapat, implementasi kebijakan PPDB selama ini masih terlihat sebagai agenda besar yang memerlukan penataan kelolaan kebijakan lebih lanjut. Ketika kebijakan dikelola dengan baik, maka dampaknya akan dirasakan oleh masyarakat luas, yang memiliki keinginan mendapatkan pendidikan yang berkeadilan, transparan dan akuntabel. Situasi seperti ini, akan berdampak pada motivasi yang lebih tinggi bagi peserta didik dalam proses pembelajaran di sekolah tujuan mereka. Inilah yang membedakan penelitian ini dari penelitian sebelumnya yang dilakukan Desi Wulandari dkk (2018) tentang tentang Pengaruh Penerimaan Peserta Didik Baru Melalui Sistem Zonasi Terhadap Prestasi Belajar Siswa. Justru dengan penata kelolaan yang baik, motivasi dan prestasi belajar menjadi lebih baik.

Selain itu, Pemerintah Kota Padang dapat menetapkan kebijakan 
alternatif yang dapat memberikan peluang yang sama bagi masyarakat miskin yang ingin mendapatkan pembelajaran di sekolah yang diminati sesuai dengan sistem zonasi yang sudah ditetapkan.

KESIMPULAN

Sesuai dengan peraturan permendikbud, kebijakan PPDB sistem zonasi di Kota Padang adalah strategis terutama diera digital ini. Hal ini, karena kebijakan ini dapat menjamin kemudahan dalam akses pelayanan pendidikan, transparansi, akuntabilitas dan keadilan bagi masyarakat. Namun demikian, kebijakan PPDB dengan sistem zonasi di Kota Padang belum terlaksana sebagaimana mestinya, sehingga berdampak pada semakin sulitnya mewujudkan capaian tujuan kebijakan. Sebaiknya, Pemerintah Kota Padang berusaha untuk mengoptimal capaian tujuan kebijakan dengan fokus pada terpenuhinya kebutuhan masyarakat dalam memperoleh pendidikan.

DAFTAR PUSTAKA

Winarno, Budi. 2002. Kebijakan Publik

Teori dan Proses. Yogyakarta:

Media Pressindo

Mulyadi, D. 2016. Studi Kebijakan

Publik dan Pelayanan Publik:

Konsep dan Aplikasi Proses

Kebijakan Publik berbasis Analisis

Bukti untuk Pelayanan Publik.

Bandung: Alfabeta,

Dunn, W. 1999 Pengantar Analisis

Kebijakan Publik. Yogyakarta:

Gadjah Mada University Press
Yusran R. 2007. Evaluasi Dampak Kebijakan Pemekaran Daerah di Indonesia: Studi Daerah Pemekaran Kabupaten Solok Selatan. Jurnal Demokrasi. Vol. 6 No. 2

Retrievedfrom

http://ejournal.unp.ac.id/index. $\mathrm{php} / \mathrm{jd} /$ article/view/1138

Permendibud No. 51 Tahun 2018 Yang Mengatur Tentang Penerimaan Peserta Didik Baru.

Permendibud No. 20 Tahun 2019 Yang Mengatur Tentang Perubahan Atas Peraturan Menteri Pendidikan dan Kebudayaan No. 51 Tahun 2018 Tentang Penerimaan Peserta Didik Baru.

Pergub No. 22 Tahun 2018 Yang Mengatur Tentang Penerimaan Peserta Didik Baru.

Permendibud No. 44 Tahun 2019 Yang Mengatur Tentang Penerimaan Peserta Didik Baru.

Pergub No. 40 Tahun 2020 Yang Mengatur Tentang Penerimaan Peserta Didik Baru. "Sistem Zonasi Bukan Untuk PPDB Saja" ,https://nasional.sindonews.com/re ad/1412721/15/mendikbud-sistemzonasi-bukan-untuk-ppdb-saja1560878685,

"Mendikbud Sebut Penerapan Zonasi Sekolah Bersifat Fleksibel"

https://www.indovoices.com/p endidikan/mendikbud-sebutpenerapan-zonasi-sekolahbersifat-fleksibel/, diakses 16 Desember 